\title{
PENGARUH MODEL PEMBELAJARAN STUDENT FACILITATOR AND EXPLAINING TERHADAP KEMAMPUAN BERPIKIR KRITIS MATEMATIS SISWA KELAS VIII MTS HAFIZUL IKHSAN AEK PAING
}

\section{THE EFFECT OF THE STUDENT FACILITATOR AND EXPLAINING LEARNING MODEL ON CRITICAL THINKING ABILITY MATHEMATICS OF CLASS VIII MTS HAFIZUL IKHSAN AEK PAING}

\author{
INDAH FITRIA RAHMA ${ }^{1}$, SITI SUHARNI SIMAMORA ${ }^{2}$, SHENA ${ }^{3}$ \\ 1,2,3 Program Studi Pendidikan Matematika, FKIP Universitas Labuhanbatu \\ Jalan Sisingamangaraja No. 126A, KM. 3,5 Aek Tapa Rantauprapat \\ email:1indahfitria286@gmail.com, ${ }^{2}$ sitisuharnisimamora72@gmail.com, ${ }^{3}$ shena2594@gmail.com
}

\begin{abstract}
Abstrak
Penelitian ini bertujuan untuk mengetahui ada tidaknya pengaruh model pembelajaran Student Facilitator and Explaining terhadap kemampuan berpikir kritis matematis siswa kelas VIII MTs Hafizul Ikhsan Aek Paing sebelum diberi perlakuan (pretes) dan sesudah diberi perlakuan (postes) pada kelas eksperimen. Penelitian ini merupakan penelitian eksperimen semu. Populasi dalam penelitian ini adalah seluruh kelas VIII MTs Hafizul Ikhsan Aek Paing yang berjumlah 74 orang. Sedangkan sampel yang digunakan pada penelitian ini adalah kelas VIII-A berjumlah 37 orang. Sampel penelitian ditentukan dengan teknik simple random sampling. Pengumpulan data dengan menggunakan tes kemampuan berpikir kritis matematis dengan soal uraian berjumlah 4 butir. Data dianalisis menggunakan uji normalitas dan uji hipotesis yaitu paired samples $t$-test. Hasil penelitian menunjukkan bahwa rata-rata nilai posttest adalah 75,76 lebih tinggi dari rata-rata nilai pretest 32,52 dan presentase kenaikannya adalah $132,96 \%$. Dari hasil uji normalitas diperoleh bahwa data berdistribusi normal yaitu $0,248>0,05$ dan uji hipotesis diperoleh nilai $T_{\text {tabel }}<T_{\text {hitung }}(2,028<13,31)$. Dapat disimpulkan bahwa adanya perbedaan yang signifikan menunjukkan bahwa terdapat pengaruh dengan menggunakan model pembelajaran Student Facilitator and Explaining terhadap kemampuan berpikir kritis matematis siswa.
\end{abstract}

\section{Kata kunci: Student Facilitator and Explaining, Kemampuan Berpikir Kritis Matematis}

\begin{abstract}
This study aims to determine whether there is influence of learning model of Student Facilitator and Explaining on mathematical critical thinking ability of grade VIII students of MTs Hafizul Ikhsan Aek Paing before being treated (pretest) and after being treated (postes) in experiment class. This research is a quasi-experimental research. The population in this study is the entire class VIII MTS Hafizul Ikhsan Aek Paing which amounted to 74 people. While the sample used in this study is class VIII-A amounted to 37 people. The sample is determined by simple random sampling technique. Data collection using mathematical critical thinking ability test with 4 item description description. Data were analyzed using normality test and hypothesis test that paired samples $t$-test. The results showed that the average posttest value was 75.76 higher than the average pretest value of 32.52 and the percentage increase was $132.96 \%$. From the normality test results obtained that the normal distribution data that is $0.248>0.05$ and hypothesis test obtained value Ttable $<$ Thitung $(2.028<13.31)$. It can be concluded that the existence of significant differences indicate that there is influence by using student facilitator and explaining learning model to student's mathematical critical thinking ability.
\end{abstract}

Keywords: Mathematical critical thinking ability, Student Facilitator and Explaining 


\section{Pendahuluan}

Menurut Badan Nasional Standar Pendidikan menyebutkan bahwa matematika merupakan ilmu universal yang mendasari perkembangan teknologi modern, mempunyai peran penting dalam berbagai disiplin ilmu dan mengembangkan daya pikir manusia. Matematika merupakan salah satu bagian dari pendidikan yang dapat melatih peserta didik untuk berpikir kritis. Pembelajaran matematika memiliki tujuan untuk membentuk kemampuan nalar pada diri peserta didik. Sikap dan cara berpikir tersebut dapat dikembangkan melalui proses pembelajaran matematika[1].

Matematika adalah ilmu yang mempelajari tentang logika berfikir dan bernalar. Oleh karena itu matematika digunakan sebagai alat bantu untuk mengatasi masalah-masalah pada bidang lainnya, sehingga matematika memiliki peranan penting dalam kehidupan sehari-hari. Dengan belajar matematika, siswa diharapkan mampu berfikir logis dan sistematis. Serta dapat mengatasi masalah sehari-hari[2].

Banyak faktor yang menyebabkan rendahnya mutu pendidikan matematika, ada faktor internal dan ada faktor eksternal. Faktor internal misalnya banyak siswa yang beranggapan bahwa belajar matematika itu sangatlah sulit, karena karakteristik matematika yang penuh dengan perhitungan, berfikir logis, angka-angka dan rumus-rumus yang membingungkan, faktor fisik, misalnya, keterbelakangan mental, fungsi otak yang kurang baik dan bakat seseorang. Faktor lainnya yaitu faktor eksternal, misalnya cara mengajar guru yang kurang menyenangkan sehingga siswa sulit untuk memahaminya dan kurangnya fasilitas penunjang dalam pembelajaran[3].

Kemampuan berpikir kritis menjadi salah satu standar kompetensi lulusan satuan pendidikan yang tertuang pada Permendiknas Nomor 23 Tahun 2006. Orang yang berpikir kritis dapat memberikan jawaban atau argumen yang logis berdasarkan pengetahuan yang dimilikinya. Oleh sebab itu, kemampuan berpikir kritis sangat dibutuhkan dalam pemecahan atau pencarian solusi terhadap masalah yang berkembang. Menurut Fisher mengemukakan bahwa kemampuan berpikir kritis itu sendiri adalah kemampuan menginterpretasi, menganalisis, dan mengevaluasi gagasan dan argument[4]. Dari informasi yang diterima kemudian diperiksa dan dibandingkan dengan pengetahuan dan pemahaman yang dimiliki sebelumnya akhirnya mampu memberikan kesimpulan terhadap informasi tersebut dengan alasan yang tepat.

Siswa akan mampu mengkomunikasikan dan membuat karya yang kreatif ketika siswa mampu mengkritisi suatu permasalahan. Oleh karena itu kemampuan berpikir kritis menjadi sangat penting dimiliki siswa. Berpikir kritis adalah kemampuan siswa dalam mengenali suatu permasalahan. Secara sederhana berpikir kritis dapat dimaknai sebagai kemampuan menilai kebenaran suatu pernyataan yang diberikan dengan menggunakan berbagai cara. Cara tersebut meliputi proses analisis, pemberian alasan, penilaian, sintesis, dan lain-lain. Dengan demikian kita sadari bersama bahwa pentingnya kemampuan berpikir kritis ada pada diri siswa.

Berdasarkan hasil wawancara dengan guru mata pelajaran matematika MTs Hafizul Ikhsan Aek Paing dengan ibu Supiani S.Pd, diperoleh informasi bahwa banyak siswa tidak fokus dan merasa bosan, hal ini terjadi karena mereka menganggap matematika itu sulit. Selain itu, daya tangkap siswa saat guru menerangkan juga masih rendah. Ibu Supiani S.Pd juga mengungkapkan bahwa kemampuan berpikir kritis siswa rendah. Hal ini dikarenakan model pembelajaran yang digunakan guru bersifat monoton, guru sering menggunakan model konvensional yaitu metode ceramah tanpa melibatkan keaktifan siswa. Akibatnya siswa menjadi pasif dan kemampuan berpikir kritis siswa menjadi rendah.

Berpikir kritis merupakan proses mental untuk menganalisis informasi yang diperoleh. Informasi tersebut didapatkan melalui pengamatan, pengalaman, komunikasi, atau membaca". Berpikir kritis adalah sebuah proses sistematis yang memungkinkan siswa untuk merumuskan dan mengevaluasi keyakinan pendapat mereka sendiri[5]. Sedangkan menurut Gerhand berpikir kritis merupakan suatu proses kompleks yang melibatkan penerimaan dan penguasaan data, analisis data, evaluasi data dan mempertimbangkan aspek kualitatif dan kuantitatif, serta membuat seleksi atau membuat keputusan berdasarkan hasil evaluasi[6]. Indikator berpikir kritis adalah sebagai berikut[7]:

Tabel 1. Indikator Kemampuan Berpikir Kritis Matematis Siswa

\begin{tabular}{|l|l|}
\hline \multicolumn{1}{|c|}{ Indikator Umum } & \multicolumn{1}{c|}{ Indikator } \\
\hline 1. Menginterpretasi & $\begin{array}{l}\text { Memahami masalah yang ditunjukkan dengan menulis diketahui } \\
\text { maupun yang ditanyakan soal dengan tepat. }\end{array}$ \\
\hline
\end{tabular}

Indah Fitria Rahma1, Siti Suharni Simamora2, Shena3

Pengaruh Model Pembelajaran Student Facilitator and Explaining terhadap

Kemampuan Berpikir Kritis Matematis Siswa Kelas VIII MTs Hafizul Ikhsan Aek Paing 


\begin{tabular}{|l|l|}
\hline 2. Menganalisis & $\begin{array}{l}\text { Mengidentifikasi hubungan-hubungan antara pernyataan- } \\
\text { pernyataan, pertanyaan-pertanyaan, dan konsep-konsep yang } \\
\text { diberikan dalam soal yang ditunjukkan dengan membuat model } \\
\text { matematika dengan tepat dan memberi penjelasan dengan tepat. }\end{array}$ \\
\hline 3. Mengevaluasi & $\begin{array}{l}\text { Menggunakan strategi yang tepat dalam menyelesaikan soal, } \\
\text { lengkap dan benar dalam melakukan perhitungan. }\end{array}$ \\
\hline 4. Menginferensi & Membuat kesimpulan dengan tepat. \\
\hline
\end{tabular}

Guru hendaknya menggunakan model pembelajaran yang melibatkan keaktifan siswa dalam proses pembelajaran matematika, sehingga diharapkan siswa merasa dihargai, dapat mengembangkan potensi karena adanya timbal balik/komunikasi dua arah antara guru dan siswa dan kemampuan berpikir kritis siswa menjadi lebih baik. Jadi model pembelajaran yang digunakan setiap pertemuan tidak monoton hanya ceramah, tanya jawab, penugasan, dan lain-lain. Akan tetapi dalam setiap pertemuan menggunakan model pembelajaran yang bervariasi yang tentunya disesuaikan dengan situasi dan kondisi siswa dan materi yang diajarkan, karena dalam pencapaian hasil belajar yang maksimal siswa harus mencapai ketuntasan indikator dari setiap aspek pembelajaran yang diterapkan oleh guru[8].

Pembelajaran merupakan aktivitas dan proses yang sistematis dan sistemik yang terdiri dari beberapa komponen yaitu: guru, kurikulum, anak didik, fasilitas, dan administrasi. Masing-masing komponen tidak bersifat parsial atau berjalan sendiri-sendiri, tetapi harus berjalan secara teratur, saling bergantung, komplementer dan berkesinambungan. Untuk itu diperlukan rancangan dan pengelolaan belajar yang baik yang dikembangkan dalam rangka mencapai tujuan pembelajaran[9].

Mencermati permasalahan diatas, peneliti tertarik untuk menerapkan suatu model pembelajaran yang mampu memberikan kesempatan kepada siswa untuk membangun pengetahuan berdasarkan pengalaman nyata siswa dan memotivasinya untuk ikut secara aktif dalam pembelajaran agar pembelajaran yang dilaksanakan dapat memberikan hasil yang optimal dan mampu meningkatkan kemampuan berpikir kritis matematis siswa. Dalam hal ini, peneliti merekomendasikan penggunaan model Student Facilitator and Explaining dalam upaya untuk meningkatkan kemampuan berpikir siswa khususnya kemampuan berpikir kritis.

Model pembelajaran Student Facilitator and Explaining (bermain peran) adalah merupakan pembelajaran dimana siswa atau peserta didik belajar mempresentasikan ide atau pendapat pada rekan peserta didik lainnya. Model Student Facilitator and Explaining (bermain peran) dilakukan dengan cara penguasaan siswa terhadap bahan-bahan pembelajaran melalui imajinasi dan penghayatan yang dilakukan siswa. Pengembangan imajinasi dan penghayatan yang dilakukan siswa dengan memerankan sebagai tokoh baik pada benda hidup atau benda mati. Model ini dapat dilakukan secara individu atupun secara kelompok. Oleh karenanya, model ini dapat meningkatkan motivasi belajar, antusias, keaktifan dan rasa senang dalam belajar siswa serta memiliki tujuan untuk meningkatkan penguasaan akademik.

Model pembelajaran student facilitator and explaining merupakan salah satu tipe pembelajaran kooperatif yang menekan pada struktur khusus yang dirancang untuk memengaruhi pola interaksi peserta didik dan memiliki tujuan untuk meningkatkan penguasaan materi[10]. Agar pembelajaran SFE berjalan dengan baik, maka dilakukan langkah-langkah konkrit dalam pelaksanaannya di kelas sebagaimana uraian dalam bentuk tabel berikut ini[11].

Tabel 2. Tahapan PembelajaranTipe SFE (Student Facilitator and Explaining)

\begin{tabular}{|c|l|l|l|}
\hline No & \multicolumn{1}{|c|}{ Tahap } & \multicolumn{1}{|c|}{ Aktivitas Guru Aktivitas Siswa } \\
\hline 1 & $\begin{array}{l}\text { Informasi } \\
\text { Kompetensi }\end{array}$ & $\begin{array}{l}\text { Menyampaikan kompetensi yang } \\
\text { harus dicapai oleh siswa }\end{array}$ & $\begin{array}{l}\text { Mendengarkan dan } \\
\text { mencatat kompetensi yang } \\
\text { harus diketahui }\end{array}$ \\
\hline 2 & Sajian materi & $\begin{array}{l}\text { Menyajikan materi secara jelas, } \\
\text { singkat, sederhana dan } \\
\text { menyeluruh }\end{array}$ & $\begin{array}{l}\text { Mendengarkan, } \\
\text { mencermati, menganalisa, } \\
\text { mencatat, dan bertanya } \\
\text { apabila perlu }\end{array}$ \\
\hline 3 & $\begin{array}{l}\text { Siswa } \\
\text { mengembangkan } \\
\text { materi }\end{array}$ & Mengontrol dan mengarahkan & $\begin{array}{l}\text { Mengembangkan materi } \\
\text { dengan cara memperluas, } \\
\text { Memperdalam materi yang } \\
\text { telah disampaikan }\end{array}$ \\
\hline
\end{tabular}




\begin{tabular}{|c|c|c|c|}
\hline 4 & $\begin{array}{l}\text { Siswa } \\
\text { menjelaskan } \\
\text { pada siswa yang } \\
\text { lain }\end{array}$ & $\begin{array}{l}\text { Mengatur alur jalannya } \\
\text { penjelasan pengembangan materi } \\
\text { ajar masing-masing siswa }\end{array}$ & $\begin{array}{l}\text { Hasil pengembangan itu, } \\
\text { dijelaskan pada siswa yang } \\
\text { lainnya. Jadi masing- } \\
\text { masing siswa memerankan } \\
\text { diri sebagai guru belajar }\end{array}$ \\
\hline 5 & Kesimpulan & $\begin{array}{l}\text { Membuat kesimpulan akhir dari } \\
\text { pembelajaran }\end{array}$ & $\begin{array}{l}\text { Mencatat dan ikut serta } \\
\text { dalam pengambilan } \\
\text { kesimpulan belajar. }\end{array}$ \\
\hline 6 & Evaluasi & $\begin{array}{l}\text { Melakukan evaluasi dengan } \\
\text { memberikan soal-soal pada siswa }\end{array}$ & $\begin{array}{lr}\text { Mengerjakan } & \text { atau } \\
\text { menjawab soal-soal yang } \\
\text { diberikan oleh guru. }\end{array}$ \\
\hline 7 & Refleksi & $\begin{array}{l}\text { Melakukan kaji ulang tentang } \\
\text { kejadian-kejadian yang terjadi } \\
\text { pada saat proses belajar } \\
\text { mengajar, dimana kelemahannya, } \\
\text { kekurangannya, maupun } \\
\text { kelebihannya dan sebagainya. }\end{array}$ & $\begin{array}{l}\text { Menyadari tentang hal-hal } \\
\text { yang dilakukan dalam } \\
\text { proses pembelajaran, atau } \\
\text { ia telah melakukan cara } \\
\text { belajar yang tepat atau } \\
\text { belum, dan seterusnya. }\end{array}$ \\
\hline
\end{tabular}

\section{Metodologi Penelitian}

Penelitian ini adalah penelitian kuantitatif dan metode yang digunakan yaitu metode penelitian quasi-eksperimen (quasi experiment) dengan rancangan kelompok pretest-postest eksperimen. Penelitian ini bertujuan untuk mengetahui pengaruh Model Pembelajaran Student Facilitator and Explainning terhadap kemampuan berpikir kritis matematis siswa. Penelitian ini dilaksanakan di MTs Hafizul Ikhsan Aek Paing. Adapun waktu penelitian dilaksanakan pada semester I, yang direncanakan pada bulan Juli dengan setiap kali pertemuan 80 menit. Desain perlakuan dapat dilihat pada Tabel 3 sebagai berikut:

Tabel 3. Desain Perlakuan

\begin{tabular}{|c|c|c|c|}
\hline Kelompok & Kemampuan Awal & Perlakuan & Kemampuan Akhir \\
\hline Eksperimen & O1 & $\mathrm{X}$ & O2 \\
\hline
\end{tabular}

Keterangan:

O1 : Pre-test (tes awal sebelum proses belajar mengajar dimulai dan belum diberikan perlakuan)

O2 : Post-test (tes akhir setelah proses belajar mengajar berlangsung dan diberikan perlakuan)

$\mathrm{X} \quad$ : Perlakuan (Treatment) melaksanakan pembelajaran menggunakan model pembelajaran Student Facilitator and Explaining.

Sampel pada penelitian ini adalah siswa kelas VIII-A sebagai kelas eksperimen menggunakan model pembelajaran Student Facilitator and Explaining yang berjumlah 37 siswa.Instrumen yang digunakan dalam penelitian ini adalahtes kemampuan berpikir kritis siswa sebanyak 5 soal yang digunakan untuk pre-test dan post-test. Analisis untuk pengujian hipotesis menggunakan uji t yaitu Paired Samples T-Test, namun sebelum dilakukan uji t terlebih dahulu dilakukan uji normalitas.

\section{Hasil dan Pembahasan Penelitian \\ Hasil Pretest dan Posttest}

Perbandingan hasil pretest dan posttest kemampuan berpikir kritis matematis siswa kelas VIII-A MTs Hafizul Ikhsan Aek Paing dapat dilihat pada tabel 4 berikut ini :

Tabel 4. Perbandingan Hasil Pretest dan Posttest kemampuan berpikir kritis siswa

\begin{tabular}{|c|c|c|c|c|}
\hline \multirow{2}{*}{ No } & \multirow{2}{*}{ Kategori } & \multirow{2}{*}{ Interval Nilai } & \multicolumn{2}{|c|}{ Frekuensi } \\
\cline { 3 - 5 } & & & Pretest & Posttest \\
\hline 1 & Tinggi & $66-95$ & 4 & 25 \\
\hline 2 & Sedang & $36-65$ & 12 & 12 \\
\hline
\end{tabular}




\begin{tabular}{|c|c|c|c|c|}
\hline 3 & Rendah & $6-35$ & 21 & 0 \\
\hline \multicolumn{3}{|c|}{ Jumlah } & 37 & 37 \\
\hline \multicolumn{3}{|c|}{ Mean } & 32.52 & 75.76 \\
\hline \multicolumn{3}{|c|}{ StandarDeviasi } & 20.55 & 15.97 \\
\hline
\end{tabular}

Berdasarkan tabel 4 maka dapat dilihat adanya perubahan antara frekuensi pretest dan posttest. Lebih jelasnya dapat dilihat pada diagram batang perbandingan hasil pretest dan posttest dibawah ini:

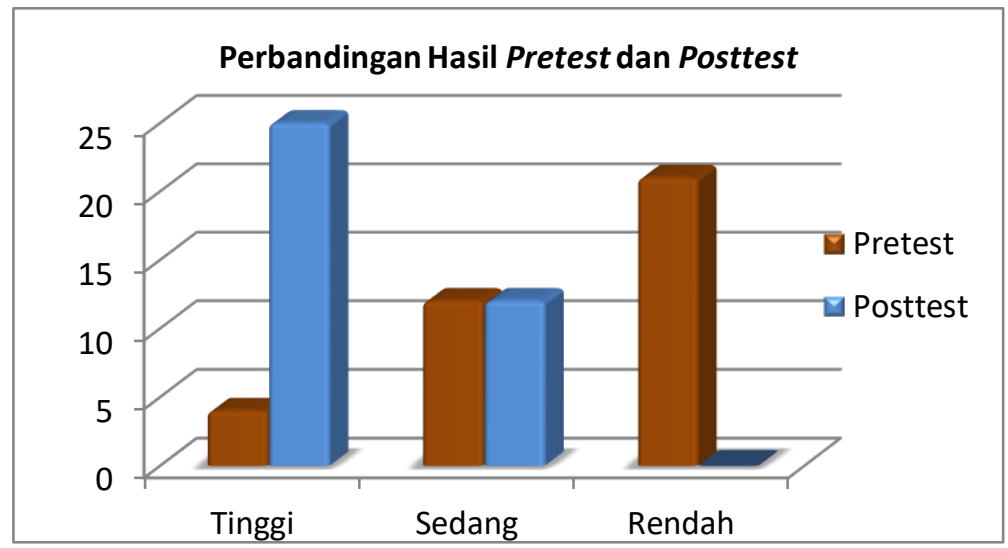

Gambar 1. Perbandingan Hasil Pretest dan Posttest

Dari grafik diatas, sebelum diberikan perlakuan, siswa yang memiliki kategori tinggi hanya 4 orang, namun setelah diberi perlakuan siswa yang memiliki kategori tinggi menjadi 25 orang. Untuk kategori sedang, sebelum dan sesudah diberi perlakuan ada 12 orang. Kemudian sebelum diberikan perlakuan, siswa yang memiliki kategori rendah sebanyak 21 orang, namun setelah diberikan perlakuan tidak ada siswa yang memiliki kategori rendah. Terlihat jelas bahwa perlakuan (treatment) tersebut mempengaruhi hasil yang diperoleh siswa.

\section{Hasil Analisis Kemampuan Berpikir Kritis Matematis Siswa dengan Menggunakan Model Student Facilitator and Explaining}

Hasil kemampuan berpikir kritis matematis siswa kelas VIII-A dapat diketahui dari hasil posttest. Hasil evaluasi kemampuan berpikir kritis siswa per indikator ditunjukkan pada tabel 5 yang diukur berdasarkan pedoman penskoran kemampuan berpikir kritis siswa.

Tabel 5. Presentase Kemampuan Berpikir Kritis Matematis Siswa per Indikator

\begin{tabular}{|c|l|c|c|}
\hline No & \multicolumn{1}{|c|}{ Indikator } & Presentase (\%) & Kategori \\
\hline 1 & Interpretasi & 98.65 & Sangat tinggi \\
\hline 2 & Analisis & 81.08 & Tinggi \\
\hline 3 & Evaluasi & 69.59 & Sedang \\
\hline 4 & Inferensi & 72.13 & Tinggi \\
\hline
\end{tabular}

Keterangan:

(1) Interpretasi: Memahami masalah

(2) Analisis : Mengidentifikasi dengan membuat model matematika dari soal

(3) Evaluasi : Menggunakan strategi yang tepat dalam menyelesaikan soal

(4) Inferensi : membuat kesimpulan yang tepat sesuai dengan konteks masalah

Kemampuan berpikir kritis siswa perindikator tersebar dalam 3 kategori yaitu sangat tinggi, tinggi dan sedang dengan kemampuan berpikir kritis siswa dalam menginterpretasi termasuk dalam 
kategori sangat tinggi yaitu $98,65 \%$, dan menganalisis dan menginferensi termasuk dalam kategori tinggi yaitu $81,08 \%$ dan $72,13 \%$, serta mengevaluasi termasuk kategori sedang yaitu $69,59 \%$. Hasil ini membuktikan bahwa kemampuan berpikir kritis siswa menjadi lebih baik setelah menggunakan model pembelajaran Student Facilitator and Explaining.

Berdasarkan perhitungan ujinormalitas diperoleh nilai $\chi_{\text {hitung }}^{2}<\chi_{\text {tabel }}^{2}$ untuk pre-test yaitu $1,35<0,14$ dan post test yaitu $-1,04<0,14(\alpha=5 \%)$ yang berarti bahwa data pre-test dan post-test berdistribusi normal. Maka dapat disimpulkan bahwa data pre-test dan post-test berdistribusi normal. Hasil uji t diperoleh nilai thitung >ttabel yaitu13,31 > 2,028 maka Ho ditolak yang artinya terdapat pengaruh model pembelajaran Student Facilitator and Explaining terhadap kemampuan berpikir kritis matematis siswa dengan pemberian pretest dan posttest.

Demikian dapat disimpulkan bahwa terdapat pengaruh model pembelajaran Student Facilitator and Explaining terhadap kemampuan berpikir kritis matematis siswa kelas VIII MTs Hafizul Ikhsan Aek Paing. Sedangkan kemampuan berpikir kritis siswa lebih baik setelah diberikan perlakuan model pembelajaran Student Facilitator and Explaining, hal ini terlihat dari nilai rata-rata kelas eksperimen mengalami peningkatan dari rata-rata nilai pretest 32,52 menjadi rata-rata nilai postest 75,76 dengan persentase kenaikan sebesar $132,98 \%$. Selanjutnya dilihat dari kategori hasil pretest dan posttest sebelum diberikan perlakuan, siswa yang memiliki kategori tinggi hanya 4 orang namun setelah diberi perlakuan siswa yang memiliki kategori tinggi menjadi 25 orang. Untuk kategori sedang, sebelum dan sesudah diberi perlakuan ada 12 orang. Kemudian untuk kategori rendah sebelum diberikan perlakuan sebanyak 21 orang, namun setelah diberikan perlakuan tidak ada siswa yang memiliki kategori rendah. Serta dapat dilihat dari kenaikan per indikator kemampuan berpikir kritis siswa yang tersebar dalam 3 kategori yaitu sangat tinggi, tinggi dan sedang dengan kemampuan berpikir kritis siswa dalam menginterpretasi termasuk dalam kategori sangat tinggi yaitu $98,65 \%$, dan menganalisis dan menginferensi termasuk dalam kategori tinggi yaitu $81,08 \%$ dan $72,13 \%$, serta mengevaluasi termasuk kategori sedang yaitu $69,59 \%$.

\section{Pembahasan Penelitian}

Penelitian ini dilakukan untuk mengetahui pengaruh model pembelajaran Student Facilitator and Explaining (SFE) terhadap kemampuan berpikir kritis matematis siswa pada materi Sistem Persamaan Linier Dua Variabel (SPLDV) di kelas VIII MTs Hafizul Ikhsan Aek Paing. Dalam penelitian ini, peneliti menggunakan satu kelas yaitu kelas eksperimen pada kelas VIII-A yang berjumlah 37 siswa dengan menggunakan model pembelajaran Student Facilitator and Explaining. Data dikumpulkan menggunakan teknik pengumpulan data berupa instrumen tes yaitu dengan memberikan pretes dan postes pada kelas eksperimen.

Berdasarkan hasil yang diperoleh data kelas eksperimen yang mempunyai rata-rata nilai pretest sebesar 32,52 , dan rata-rata nilai posttest sebesar 75,76 dan rata-rata peningkatan kemampuan berpikir kritis matematis siswa (selisih pretest dan posttest) sebesar 43,24 . Hasil tersebut menunjukkan kemampuan berpikir kritis siswa lebih baik setelah menggunakan model pembelajaran Student Facilitator and Explaining (SFE) dilihat dari hasil pretest dan posttest di kelas VIII-A. Setelah dikelompokkan berdasarkan interval nilai diperoleh siswa yang memiliki kategori tinggi hanya 4 orang, namun setelah diberi perlakuan siswa yang memiliki kategori tinggi menjadi 25 orang. Untuk kategori sedang, sebelum dan sesudah diberi perlakuan ada 12 orang. Kemudian sebelum diberikan perlakuan, siswa yang memiliki kategori rendah sebanyak 21 orang, namun setelah diberikan perlakuan tidak ada siswa yang memiliki kategori rendah. Terlihat jelas bahwa perlakuan (treatment) tersebut mempengaruhi hasil yang diperoleh siswa.

Dalam hal ini, siswa belum dapat mencapai nilai maksimal karena pada indikator yang kedua dan ketiga yakni analisis dan evaluasi, masih banyak siswa yang tidak tepat dalam mengidentifikasi hubungan, pernyataan, dan konsep yang diberikan pada soal, serta penggunaan strategi dan penyelesaian soal dalam melakukan perhitungan masih banyak salah, sehingga di dapat nilai tertinggi hasil posttest siswa yaitu 95,31 dan belum mencapai nilai maksimal 100. Akan tetapi siswa dikatakan mampu berpikir kritis setelah menggunakan model student facilitator and explaining terlihat dari presentase nilai yang diperoleh siswa per indikator yaitu interpretasi $98,65 \%$, analisis $81,08 \%$, evaluasi $69,59 \%$ dan inferensi $72,13 \%$.

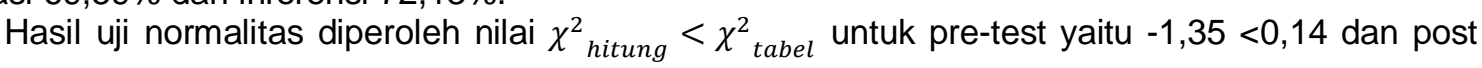
test yaitu $-1,04<0,14(\alpha=5 \%)$ sehingga dikatakan data berdistribusi normal. Setelah data dikatakan normal, maka dilakukan uji hipotesis dengan menggunakan paired samples T-Test. Hasil yang diperoleh dari uji paired samples T-Test taraf signifikansi $(\alpha=5 \%)$ dengan hasil thitung>ttabel yaitu13,31 
$>2,028$ maka $\mathrm{H}_{0}$ ditolak dan $\mathrm{Ha}$ diterima, berarti ada perbedaan yang signifikansi terhadap pengukuran data pretest dan posttest. Maka, melalui uji paired samples T-Test terbukti ada pengaruh yang signifikan dalam model pembelajaran Student Facilitator and Explaining terhadap kemampuan berpikir kritis matematis siswa dengan pemberian pretest dan posttest.

Dari hasil pengujian hipotesis penelitian diatas terlihat bahwa ada pengaruh model pembelajaran Student Facilitator and Explaining terhadap kemampuan berpikir matematis siswa karena model ini dapat meningkatkan kemampuan siswa untuk mengembangkan materi ajar secara mandiri, menumbuhkan kemampuan siswa dalam menyampaikan pengetahuan yang dimilikinya kepada temannya, dan saling jelas-menjelaskan satu sama lainnya[11].

Kemampuan berpikir kritis siswa juga lebih baik setelah diberikan perlakuan model pembelajaran Student Facilitator and Explaining, hal ini terlihat dari nilai rata-rata kelas eksperimen mengalami peningkatan dari rata-rata nilai pretest 32,52 menjadi rata-rata nilai postest 75,76 dengan persentase kenaikan sebesar $132,98 \%$. Selanjutnya dilihat dari kategori hasil pretest dan posttest sebelum diberikan perlakuan, siswa yang memiliki kategori tinggi hanya 4 orang namun setelah diberi perlakuan siswa yang memiliki kategori tinggi menjadi 25 orang. Untuk kategori sedang, sebelum dan sesudah diberi perlakuan ada 12 orang. Kemudian untuk kategori rendah sebelum diberikan perlakuan sebanyak 21 orang, namun setelah diberikan perlakuan tidak ada siswa yang memiliki kategori rendah. Serta dapat dilihat dari kenaikan per indikator kemampuan berpikir kritis siswa yang tersebar dalam 3 kategori yaitu sangat tinggi, tinggi dan sedang dengan kemampuan berpikir kritis siswa dalam menginterpretasi termasuk dalam kategori sangat tinggi yaitu $98,65 \%$, dan menganalisis dan menginferensi termasuk dalam kategori tinggi yaitu $81,08 \%$ dan $72,13 \%$, serta mengevaluasi termasuk kategori sedang yaitu $69,59 \%$. Hal ini sesuai dengan penelitian relevan yang dilakukan oleh Windi Setiawati (2013) yang menyatakan bahwa adanya peningkatan kemampuan berpikir kritis siswa terhadap model pembelajaran student facilitator and explaining pada mata pelajaran IPA siswa kelas IVC SD Muhammadiyah 2 Kauman Surakarta Tahun 2013.

\section{Kesimpulan}

Berdasarkan hasil penelitian dan pembahasan dapat disimpulkan bahwa terdapatnya pengaruh model pembelajaran Student Facilitator and Explaining terhadap kemampuan berpikir kritis matematis siswa yang diterapkan di kelas VIII-A MTs Hafizul Ikhsan Aek Paing tahun pembelajaran 2017/2018. Hal ini dapat dibuktikan dari nilai rata-rata kelas eksperimen yang diajarkan sebelum dan sesudah diberi perlakuan dengan model student facilitator and Explaining yaitu $(32,52<$ 75,76).Demikian juga berdasarkan hasil perhitungan uji paired samples $t$-test manual menunjukkan bahwa thitung $>$ tabel yaitu13,31 > 2,028 yang artinya terdapat perbedaan yang signifikan dan menggunakan bantuan SPSS Statistic 17 diperoleh nilai sig. (2-tailed) sebesar 0,000 < 0,05. Maka, melalui uji paired samples $T$-Test terbukti ada pengaruh yang signifikan dalam model pembelajaran Student Facilitator and Explaining terhadap kemampuan berpikir kritis matematis siswa dengan pemberian pretest dan posttest. Kemampuan berpikir kritis matematis siswa setelah menggunakan model pembelajaran student facilitator and explaining menjadi lebih baik, hal ini diketahui melalui nilai rata-rata pretest (sebelum adanya perlakuan) dan nilai rata-rata posttest (sesudah diberi perlakuan) yakni $32,52<75,76$, dalam hal ini berarti nilaimeningkat sebesar $132,98 \%$. Demikian juga dilihat dari persentase nilai pretest dan posttest per indikator yaitu interpretasi dengan kategori sangat tinggi memiliki presentase nilai sebesar $98,65 \%$, analisis dengan kategori tinggi presentase nilai $81,08 \%$ dan evaluasi dengan kategori sedang presentase nilai 69,59 serta inferensi dengan kategori tinggi presentase nilai $72,13 \%$.

\section{Daftar Pustaka}

[1] Lilyan, R. 2015. Analisis Kemampuan Berpikir Kritis Siswa dengan Pembelajaran Model 4k Materi Geometri Kelas VIII Ditinjau dari Gaya Kognitif Siswa. Skripsi Pendidikan Matematika, Universitas Negeri Semarang

[2] Wiradnyana, dkk. 2014. Pengaruh Model Pembelajaran Student Facilitator and Explaining terhadap Kemampuan Pemecahan Masalah Matematika Siswa Kelas V. Jurnal Mimbar PGSD Universitas Pendidikan Ganesha

[3] Siregar, S.U. (2016). Perbandingan Hasil Belajar Matematika Siswa Menggunakan Pembelajaran Kontekstual Tipe VAK (Visual Auditory Kinestetik) dengan Pembelajaran Kooperatif Tipe ATI

Indah Fitria Rahma1, Siti Suharni Simamora2, Shena3

Pengaruh Model Pembelajaran Student Facilitator and Explaining terhadap

Kemampuan Berpikir Kritis Matematis Siswa Kelas VIII MTs Hafizul Ikhsan Aek Paing 
(Aptitude Treadment Interaktion) pada Pokok Bahasan Bangun Ruang Kubus di Kelas VIII SMPN 1 Rantau Selatan. Jurnal Pembelajaran dan Matematika Sigma (JPMS). Vol. 2 No.1, hlm. 23-25. 2016

[4] Ryane, Siska. 2014. Pengaruh Penggunaan Metode Student Facilitator and Explaining dalam Pembelajaran Kooperatif terhadap Kemampuan Pemecahan Masalah Matematik dan Kemampuan Berpikir Kritis Matematik Siswa SMK di Kota Tasikmalaya. Jurnal Pendidikan dan Keguruan, Tesis Universitas Terbuka

[5] Suryosubroto. 2009. Proses Belajar Mengajar di Sekolah. Jakarta: Rineka Cipta

[6] Turohmah, 2014. Peningkatan Kemampuan Berpikir Kritis Matematis Siswa melalui Penerapan Pendekatan Open Ended. Skripsi Fakultas IImu Tarbiyah dan Keguruan Universitas Islam Negeri (UIN) Syarif Hidayatullah

[7] Karim., Normaya. 2015. Kemampuan Berpikir Kritis Siswa, dalam Pembelajaran Matematika dengan menggunakan Model Jucama di Sekolah Menengah Pertama. Jurnal Pendidikan Matematika. HIm 92-104

[8] Hrp, N.A., Rahma, I.F. 2020. Keefektifan Penerapan Model Pembelajaran Berbasis Proyek Dalam Pencapaian Aspek Kemampuan Representasi dan Komunikasi Matematis Siswa Kelas VI SD Negeri 118296 Beringin Jaya Pinang Damai. Jurnal Pendidikan Matematika (Phi). Vol. 4 No. 2 Tahun 2020

[9] Hrp, N.A., Rahma, I.F. 2020. Keefektifan Penerapan Model Pembelajaran Berbasis Proyek Dalam Pencapaian Aspek Kemampuan Representasi dan Komunikasi Matematis Siswa Kelas VI SD Negeri 118296 Beringin Jaya Pinang Damai. Jurnal Pendidikan Matematika (Phi). Vol. 4 No. 2 Tahun 2020

[10] Shoimin, Aris. 2014. 68 Model Pembelajaran Inovatif dalam Kurikulum 2013. Yogyakarta: Ar-ruzz Media

[11] Istarani dan Ridwan. 2014. 50 Tipe Pembelajaran Kooperatif. Medan: Media Persada 